\title{
The study of the qualitative composition and the quantitative content of phenolic compounds in dietary supplements with lingonberry
}

\begin{abstract}
Aim. Today, there are a lot of dietary supplements with lingonberry at the pharmaceutical market of Ukraine; therefore, the analysis and quality control of these products are relevant. In this connection, the aim of the research was to study the qualitative composition and determine the quantitative content of phenolic compounds in dietary supplements with lingonberry.

Materials and methods. Such dietary supplements as "Extract of lingonberry" (MEDAGROPROM), "Lingonberry" (Danikafarm), "Lingonberry nano" (LSS SYSTEM) were chosen for the study. The qualitative analysis was performed by thin layer chromatography (TLC), spectrophotometry was used for the quantitative determination.

Results and discussion. Hydroquinone derivatives, flavonoids and hydroxycinnamic acids were found in the dietary supplements analyzed. The total content of phenolic compounds was $8.70,0.26,0.30 \%$, flavonoids $-6.37,0.15,0.12 \%$, hydroxycinnamic acids $-0.94,0.06,0.13 \%$, and hydroquinone derivatives $-1.01,0.04,0.03 \%$ in such dietary supplements as "Extract of lingonberry" (MEDAGROPROM), "Lingonberry" (Danikafarm), "Lingonberry nano” (LSS SYSTEM), respectively.

Conclusions. The qualitative and quantitative analysis of the dietary supplements with lingonberry analyzed has been performed. "Extract of lingonberry" (MEDAGROPROM) dietary supplement meets the requirements of the State of Pharmacopoeia of Ukraine 2.0, whereas "Lingonberry" (Danikafarm) and "Lingonberry nano" (LSS SYSTEM) do not. Based on the results of the study it can be concluded that the problem of compliance of dietary supplements is relevant today and requires the introduction of regulatory documentation for the detection and determination of biologically active substances in dietary supplements. Keywords: lingonberry; spectrophotometry; analysis; phenolic compounds; dietary supplements
\end{abstract}

О. Ю. Маслов, М. А. Комісаренко, С. В. Колісник, О. В. Антоненко, О. В. Колісник, Т. А. Костіна Національний фармацевтичний університет Міністерства охорони здоров'я України, вул. Пушкінська, 53, м. Харків, 61002, Україна

Дослідження якісного складу та кількісного вмісту фенольних сполук у дієтичних добавках з брусницею

Анотація

Мета. Сьогодні на фармацевтичному ринку України існує велика кількість дієтичних добавок з брусницею, тому аналіз і контроль якості цих продуктів $€$ актуальними. У зв'язку з цим метою роботи було вивчення якісного складу та визначення кількісного вмісту фенольних сполук у дієтичних добавках з брусницею.

Матеріали та методи. Для дослідження було обрано дієтичні добавки «Екстракт брусниці» (МЕДАГРОПРОМ), «Брусниця» (Danikafarm), «Брусниця нано» (LSS SYSTEM). Якісний аналіз проводили методом тонкошарової хроматографії (TШX), для кількісного визначення використовували спектрофотометрію.

Результати та їх обговорення. У досліджуваних дієтичних добавках було виявлено похідні гідрохінону, флавоноїдів та гідроксикоричних кислот. Сумарний вміст фенольних сполук становив 8,70, 0,26, 0,30\%, флавоноїдів 6,37, 0,15, 0,12\%, гідроксикоричних кислот 0,94, 0,06, 0,13\% і похідних гідрохінону 1,01, 0,04, 0,03\% для дієтичних добавок «Екстракт брусниці» (МЕДАГРОПРОМ), «Брусниця» (Danikafarm), «Брусниця нано» (LSS SYSTEM) відповідно. 
Висновки. Проведений якісний і кількісний аналіз фенольних сполук трьох дієтичних добавок з брусницею дозволив з'ясувати, що дієтична добавка «Екстракт брусниці» (МЕДАГРОПРОМ) відповідає вимогам Державної фармакопеї України 2.0, тоді як «Брусниця» (Danikafarm) і «Брусниця нано» (LSS SYSTEM) не відповідають. Результати дослідження дозволяють констатувати, що проблема відповідності біологічно активних добавок є актуальною, тому необхідним постає введення нормативної документації на виявлення та визначення біологічно активних речовин у дієтичних добавках.

Ключові слова: брусниця; спектрофотометрія; аналіз; фенольні сполуки; дієтичні добавки

Citation: Maslov, O. Yu.; Komisarenko, M. A.; Kolisnyk, S. V.; Antonenko, O. V.; Kolisnyk, O. V.; Kostina T. A. The study of the qualitative composition and, the quantitative content of phenolic compounds in dietary supplements with lingonberry. Journal of Organic and Pharmaceutical Chemistry 2021, 19 (4), 40-46.

https://doi.org/10.24959/ophcj.21.243782

Received: 10 September 2021; Revised: 29 September 2021; Accepted: 5 October 2021

Copyright $@ 2021$, O. Yu. Maslov, M. A. Komisarenko, S. V. Kolisnyk, O. V. Antonenko, O. V. Kolisnyk, T. A. Kostina. This is an open access article under the CC BY license (http://creativecommons.org/licenses/by/4.0).

Funding: The work is a part of the studies of the National University of Pharmacy on the topic "Organic synthesis and analysis of biologically active compounds, drug development on the basis of synthetic substances" (the state registration No. 01144000943; the research period 2019-2024).

Conflict of interests: the authors have no conflict of interests to declare.

\section{- Introduction}

Lingonberry (Vaccinum vitis idaea) is small shrubs belonging to the genus Vaccinium, of Ericaceae family. Its berries mature from July to September, while the ripeness time is highly affected by the site conditions, precisely altitude, and the habitat type. Usually, higher altitudes generate later plant ripening when compared with lower elevations [1].

The main biologically active substances of lingonberry leaves and berries are phenolic compounds (arbutin, hydroquinone, gallo- and ellagotannins), flavonols (luteolin, kempferol and quercetin), hydroxycinnamic acids (chlorogenic, cumaric and ferulic acids), coumarins, organic acids [2-4]. The chemical composition of leaves and berries are approximately the same, but berries contain higher amount of phenolic compounds and organic acids; moreover, unlike leaves, berries accumulate anthocyanidin derivatives [5].

Owing to the presence of various phenolic compounds, lingonberry leaves and berries possess the antibacterial [6], anti-inflammatory [7], and antioxidant activities [8]. Extracts of lingonberry leaves have shown to possess multiple beneficial properties e.g., diuretic, analgesic and urinary antiseptic ones. They also display the anti-cough, phlegm removing, anti-inflammatory, neuroprotective, and antioxidant activity [9-11].

Nowadays at the pharmaceutical market of Ukraine one can find a number of dietary supplements for treating urological diseases. One of reasons is that $10 \%$ of the Ukrainian population has signs of chronic diseases of the genitourinary system. Another reason is a high consumer interest in purchasing dietary supplements. According to the Law of Ukraine [12] dietary supplements are not subjected to the qualitative and quantitative analysis, as a result, the quality of these products are casted doubt.

Thus, the aim of study was to determine the qualitative composition and the quantitative content of phenolic compounds in dietary supplements with lingonberry.

\section{- Materials and methods}

Rutin, arbutin, hydroquinone and chlorogenic acid were of analytical grade and purchased in Sigma-Aldrich.

Three dietary supplements with lingonberry of different Ukrainian manufactures were chosen for the analysis.

"Extract of lingonberry" contains the extract of lingonberry fruits according to the information on the label; the dosage form is drops $(30 \mathrm{~mL})$, the manufacturer is "MEDAGROPROM", Dnipro.

"Lingonberry" contains leaves and shoots of lingonberry according to the information on the label; the dosage form is tablets (100 pcs), the manufacturer is "Danikafarm", Kharkiv.

"Lingonberry nano" contains leaves and fruits of lingonberry, intercellular and intracellular liquid of lingonberry leaves and fruits according to the information on the label; the dosage form is tablets (100 pcs), the manufacturer is "LSS SYSTEM", Kharkiv.

All solvents and reagents were of analytical grade. "Sorbfil-PTSH-AF-A-UV" plates were used for the TLC analysis.

The quantitative analysis of biologically active compounds was performed on an UV-1000 UV-spectrophotometer (China) with a matched $1 \mathrm{~cm}$ quarts cell. 


\section{Preparation of standard solutions for the TLC analysis}

$0.010 \mathrm{~g}$ (accurate weight) of each arbutin, rutin, chlorogenic acid and hydroquinone was transferred into four $50 \mathrm{~mL}$ measuring flasks, dissolved in $96 \%$ ethanol and diluted to the volume with the same solvent.

Preparation of the standard solution of rutin for the spectrophotometric assay

$0.050 \mathrm{~g}$ (accurate weight) of rutin was transferred into a $100.0 \mathrm{~mL}$ measuring flask, dissolved in $96 \%$ ethanol and diluted to the volume with the same solvent. $1.0 \mathrm{~mL}$ of the solution prepared was taken, transferred into a $25.0 \mathrm{~mL}$ measuring flask and diluted to the volume with 96\% ethanol.

Preparation of the standard solution of arbutin for the spectrophotometric assay

$0.015 \mathrm{~g}$ (accurate weight) of arburin was transferred into a $100.0 \mathrm{~mL}$ measuring flask, dissolved in distilled water and diluted to the volume with the same solvent.

Preparation of the solution of berlin blue

$10.0 \mathrm{~g}$ of iron(III) chloride and $0.5 \mathrm{~g}$ of potassium hexacyanoferrate were dissolved in $100.0 \mathrm{~mL}$ of distilled water.

\section{TLC analysis assay}

The powder of 7 crushed tablets of each dietary supplement was completely dissolved in $96 \%$ ethanol, filtered into a $50.0 \mathrm{~mL}$ measuring flask and diluted to the volume with the same solvent. $5.0 \mathrm{~mL}$ of "Extract of lingonberry" (MEDAGROPROM) was taken, placed into a $25.0 \mathrm{~mL}$ measuring flask and diluted to the volume with $96 \%$ ethanol. To identify arbutin, the developing system consisting of ethyl acetate/methanol/water (100:13.5:10) was used; for flavonoids and hydroxycinnamic acids the developing system was ethyl acetate/ glacial acetic acid/formic acid/water (100:11:11:26). The samples were spotted using a $10 \mu \mathrm{L}$ micropipette with $30 \mu \mathrm{L}$ of the test solutions of the dietary supplements and $10 \mu \mathrm{L}$ of the standards solutions. The sample plates were air dried, then placed in chromatographic chambers, which were pre-saturated with the developing systems and chromatographed in ascending order. When the front of the solvent passed about $8 \mathrm{~cm}$, the plates were removed from the chambers and dried in air for $30 \mathrm{~min}$. Arbutin and hydroquinone were detected in UV light at wavelengths of 254 and $325 \mathrm{~nm}$. For the final determination of catechins, the dried plates were treated with Berlin blue solution, flavonoids and hydroxycinnamic acids were detected by $10 \%$ solution of $\mathrm{NaOH}$ in $96 \%$ ethanol.
Assay for the total content of phenolic compounds

The total amount of phenolic compounds was determined by the Folin-Ciocalteu method [13]. $3.2 \mathrm{~g}$ (accurate weight) of "Lingonberry" (Danikafarm) and "Lingonberry nano" (LSS SYSTEM) was dissolved in $96 \%$ ethanol and filtered in a $50.0 \mathrm{~mL}$ measuring flask. $5.0 \mathrm{~mL}$ of "Extract of lingonberry" (MEDAGROPROM) was dissolved in a $25.0 \mathrm{~mL}$ measuring flask and diluted to the volume with $96 \%$ ethanol. An aliquot of the solutions prepared was mixed with $1.0 \mathrm{~mL}$ of $1 \mathrm{M}$ Folin-Ciocalteu reagent, the mixture was diluted to the volume of $25.0 \mathrm{~mL}$ with $20 \% \mathrm{Na}_{2} \mathrm{CO}_{3}$ solution. The optical density of the solutions was measured at $760 \mathrm{~nm}$ in $30 \mathrm{~min}$ after preparation. The calibration curve was plotted using gallic acid, the calibration equation was $\mathrm{y}=0.1055 \mathrm{x}+0.1745\left(r^{2}=0.9951\right)$. The total amount of phenolic compounds in "Lingonberry" (Danikafarm) and "Lingonberry nano" (LSS SYSTEM) dietary supplements in 1 tablet was calculated by the following equation and expressed with reference to gallic acid:

$$
X(\%)=\frac{C_{\mathrm{x}} \cdot K_{\mathrm{dil}} \cdot m_{\mathrm{aver} \mathrm{tab}} \cdot 100 \cdot 100}{m_{\mathrm{s}} \cdot(100-W)},
$$

where $C_{\mathrm{x}}$ - is the concentration of gallic acid according to the calibration curve, $C \times 10^{-6}$, $\mathrm{g} \mathrm{mL}^{-1}$; $m_{\mathrm{s}}-$ is the sample weight, $\mathrm{g}$;

$m_{\text {aver tab }}$ - is the average mass of a tablet, g;

$K_{\text {dil }}-$ is the coefficient of dilution;

$W-$ is the percentage of moisture, $\%$.

The total content of phenolic compounds in "Extract of lingonberry" (MEDAGROPROM) dietary supplement in the total volume of drops was calculated by the equation and expressed with reference to gallic acid:

$$
X(\%)=\frac{C_{\mathrm{x}} \cdot K_{\mathrm{dil}} \cdot V_{\mathrm{drops}} \cdot 100}{V_{\mathrm{al}}},
$$

where $C_{\mathrm{x}}$ - is the concentration of gallic acid according to the calibration curve; $C \times 10^{-6}, \mathrm{~g} \mathrm{~mL}^{-1}$; $V_{\text {al }}$ - is the volume of an aliquot, $\mathrm{mL}$; $V_{\text {drops }}^{\text {al }}$ - is the total volume of drops, $\mathrm{mL}$; $K_{\mathrm{dil}}-$ is the coefficient of dilution.

Assay for the total content of flavonoids

$3.2 \mathrm{~g}$ (accurate weight) of "Lingonberry" (Danikafarm) and "Lingonberry nano" (LSS SYSTEM) was dissolved in $96 \%$ ethanol and filtered in a $50.0 \mathrm{~mL}$ measuring flask. $5.0 \mathrm{~mL}$ of "Extract of lingonberry" (MEDAGROPROM) was added to a $25.0 \mathrm{~mL}$ measuring flask and diluted to the volume with $96 \%$ 
ethanol (Solution A). An aliquot of Solution A was mixed with $1.0 \mathrm{~mL}$ of $2 \% \mathrm{AlCl}_{3}$ solution in methanol and diluted to the volume of $25.0 \mathrm{~mL}$ with $5 \%$ solution of glacial acetic acid in methanol. The solution prepared was allowed to stand for $30 \mathrm{~min}$, and its optical density was measured at $417 \mathrm{~nm}$. An aliquot of Solution A diluted to the volume of $25.0 \mathrm{~mL}$ with $5 \%$ solution of glacial acetic in methanol was used as a compensation liquid [14]. The total amount of flavonoids in "Lingonberry" (Danikafarm) and "Lingonberry nano" (LSS SYSTEM) dietary supplements in 1 tablet was calculated by the equation and expressed with reference to rutin:

$$
X(\%)=\frac{A \cdot K_{\mathrm{dil}} \cdot m_{\mathrm{avertab}} \cdot 100 \cdot 100}{A_{\mathrm{st}} \cdot m_{\mathrm{s}} \cdot(100-W)},
$$

where $A$ - is the absorbance of the test solution; $A_{\text {st }}$ - is the absorbance of the standard solution of rutin; $m_{\mathrm{s}}-$ is the sample weight, $\mathrm{g}$; $m_{\text {aver tab }}$ - is the average mass of a tablet, g; $K_{\text {dil }}-$ is the coefficient of dilution;

$W-$ is the percentage of moisture, $\%$.

The total content of flavonoids in "Extract of lingonberry" (MEDAGROPROM) dietary supplement in the total volume of drops was calculated by the equation and expressed with reference to rutin:

$$
X(\%)=\frac{A \cdot K_{\mathrm{dil}} \cdot V_{\mathrm{drops}} \cdot 100}{A_{\mathrm{st}} \cdot V_{\mathrm{al}}},
$$

where $A$ - is the absorbance of the test solution; $A_{\text {st }}$ - is the absorbance of the standard solution of rutin;

$V_{\text {al }}$ - is the volume of an aliquot, $\mathrm{mL}$;

$V_{\text {drops }}^{\text {al }}$ - is the total volume of drops, $\mathrm{mL}$;

$K_{\text {dil }}-$ is the coefficient of dilution.

Assay for the total content of hydrocinnamic acids

$3.2 \mathrm{~g}$ (accurate weight) of "Lingonberry" (Danikafarm) and "Lingonberry nano" (LSS SYSTEM) was dissolved in $96 \%$ ethanol, filtrated in a $50.0 \mathrm{~mL}$ measuring flask and diluted to the volume with the same solvent. $5.0 \mathrm{~mL}$ of "Extract of lingonberry" (MEDAGROPROM) was dissolved in a $25.0 \mathrm{~mL}$ measuring flask and diluted to the volume with $96 \%$ ethanol. An aliquot of the solutions prepared was mixed with $2.0 \mathrm{~mL}$ of $0.5 \mathrm{M} \mathrm{HCl}, 2.0 \mathrm{~mL}$ of $10 \% \mathrm{NaNO}_{2}, 2.0 \mathrm{~mL}$ of $10 \% \mathrm{Na}_{2} \mathrm{MoO}_{4}, 2.0 \mathrm{~mL}$ of $8.5 \% \mathrm{NaOH}$ and diluted to the volume of $25.0 \mathrm{~mL}$ with distilled water. The optical density of the solu- tions was measured at wavelength of $525 \mathrm{~nm}$ in 30 min after preparation. The compensation liquid was a mixture of $1.0 \mathrm{~mL}$ of the extract solution, $2.0 \mathrm{~mL}$ of $0.5 \mathrm{M} \mathrm{HCl}, 2.0 \mathrm{~mL}$ of $8.5 \% \mathrm{NaOH}$ diluted with distilled water to the volume of $25.0 \mathrm{~mL}$ [14]. The total amount of hydroxycinnamic acids in "Lingonberry" (Danikafarm) and "Lingonberry nano" (LSS SYSTEM) dietary supplements in 1 tablet was calculated by the following equation and expressed with reference to chlorogenic acid:

$$
X(\%)=\frac{A \cdot K_{\mathrm{dil}} \cdot m_{\mathrm{aver} \mathrm{tab}} \cdot 100}{188 \cdot m_{\mathrm{s}} \cdot(100-W)},
$$

where $A-$ is the absorbance of the test solution; 188 - is the specific adsorption coefficient of chlorogenic acid; $m_{\mathrm{s}}$ - is the sample weight, $\mathrm{g}$; $m_{\text {aver tab }}$ - is the average mass of a tablet, g; $K_{\text {dil }}-$ is the coefficient of dilution;

$W-$ is the percentage of moisture, \%.

The total content of hydroxycinnamic acids in "Extract of lingonberry" (MEDAGROPROM) dietary supplement in the total volume of drops was calculated by the equation and expressed with reference to chlorogenic acid:

$$
X(\%)=\frac{A \cdot K_{\mathrm{dil}} \cdot V_{\mathrm{drops}}}{188 \cdot V_{\mathrm{al}}},
$$

where $A-$ is the absorbance of the test solution; 188 - is the specific adsorption coefficient of chlorogenic acid;

$V_{\text {al }}$ - is the volume of an aliquot, $\mathrm{mL}$;

$V_{\text {drops }}^{\text {al }}$ - is the total volume of drops, $\mathrm{mL}$;

$K_{\text {dil }}-$ is the coefficient of dilution.

Assay for the total content of hydroquinone derivatives

$3.2 \mathrm{~g}$ (accurate weight) of "Lingonberry" (Danikafarm) and "Lingonberry nano" (LSS SYSTEM) was dissolved in $96 \%$ ethanol and filtrated in a $50.0 \mathrm{~mL}$ measuring flask. $5.0 \mathrm{~mL}$ of "Extract of lingonberry" (MEDAGROPROM) was dissolved in a $25.0 \mathrm{~mL}$ measuring flask and diluted to the volume with $96 \%$ ethanol. $20.00 \mathrm{~mL}$ of the aliquot of the solution obtained was evaporated to dryness on a water bath at $80^{\circ} \mathrm{C}$. The residue was dissolved in $20.00 \mathrm{~mL}$ of water, filtered through a paper filter, transferred into a separating funnel, than mixed with $1 \mathrm{~mL}$ of $2 \% 4$-amino-2,3-dimethyl1-phenylpyrazolin-5-one solution, $0.5 \mathrm{~mL}$ of $3.3 \%$ ammonia solution, $1 \mathrm{~mL}$ of $8 \%$ potassium ferricyanide and extracted twice with $20.00 \mathrm{~mL}$ of chloroform for $10 \mathrm{~min}$. The absorbance was measured 
at wavelength of $455 \mathrm{~nm}$ in $30 \mathrm{~min}$ after extraction. The compensation liquid was chloroform [14]. The total content of hydroquinone derivatives in "Lingonberry" (Danikafarm) and "Lingonberry nano" (LSS SYSTEM) dietary supplements in 1 tablet was calculated by the equation and expressed with reference to arbutin:

$$
X(\%)=\frac{A \cdot K_{\mathrm{dil}} \cdot m_{\mathrm{aver} \mathrm{tab}} \cdot 100 \cdot 100}{A_{\mathrm{st}} \cdot m_{\mathrm{s}} \cdot(100-W)},
$$

where $A-$ is the absorbance of the test solution; $A_{\text {st }}$ - is the absorbance of the standard solution of arbutin;

$m_{\mathrm{s}}$ - is the sample weight, g;

$m_{\text {aver tab }}$ - is the average mass of a tablet, g;

$K_{\text {dil }}-$ is the coefficient of dilution;

$W-$ is the percentage of moisture, \%.

The total content of hydroquinone derivatives in "Extract of lingonberry" (MEDAGROPROM) dietary supplement in the total volume of drops was calculated by the equation and expressed with reference to arbutin:

$$
X(\%)=\frac{A \cdot K_{\mathrm{dil}} \cdot V_{\mathrm{drops}} \cdot 100}{A_{\mathrm{st}} \cdot V_{\mathrm{al}}},
$$

where $A$ - is the absorbance of the test solution; $A_{\text {st }}$ - is the absorbance of the standard solution of arbutin;

$V_{\text {al }}$ - is the volume of an aliquot, $\mathrm{mL}$;

$V_{\text {drops }}-$ is the total volume of drops, $\mathrm{mL}$;

$K_{\text {dil }}-$ is the coefficient of dilution.

\section{Results and discussion}

The TLC method was applied for the qualitative analysis of dietary supplements. Hydroquinone derivatives were detected in the ethyl acetate/methanol/water (100:13.5:10) developing system. Substances were detected at wavelengths of 254 and $325 \mathrm{~nm}$. The chromatogram showed the dominant bands with the value of $R_{\mathrm{f}}=0.40$ (arbutin), $R_{\mathrm{f}}=0.80$ (hydroquinone). The chromatogram was then sprayed by $10 \%$ solution of Berlin blue; blue bands with the same $R_{\mathrm{f}}$ values were also detected.

For identification of flavonoids and hydroxycinnamic acids in the dietary supplements analyzed the ethyl acetate/glacial acetic acid/formic acid/water (100:11:11:26) developing system was used. The TLC plate was sprayed with $10 \%$ solution of $\mathrm{NaOH}$; as the result, yellow bands with values of $R_{\mathrm{f}}=0.35$ (rutin), $R_{\mathrm{f}}=0.40$ (chlorogenic acid) and $R_{\mathrm{f}}=0.55$ (hyperoside) appeared.

The total content of phenolic compounds was determined by the Folin-Ciocalteu method. As shown in Table, the highest amount of phenolic compounds was found in "Extract of lingonberry" (MEDAGROPROM) (8.70\%); at the same time, only minor amounts of phenolic compounds were found in "Lingonberry nano" (LSS SYSTEM) (0.30\%) and "Lingonberry" (Danikafarm) (0.26\%).

"Extract of lingonberry" (MEDAGROPROM) was much richer in flavonoids (6.37\%) than "Lingonberry" (Danikafarm) (0.15\%) and "Lingonberry nano" (LSS SYSTEM) (0.12\%).

The highest content of hydroxycinnamic acids was found in "Extract of lingonberry" (MEDAGROPROM) (0.94\%), followed by "Lingonberry nano" (LSS SYSTEM) (0.13\%) and "Lingonberry" (Danikafarm) (0.06\%).

The total content of hydroquinone derivatives was dominant in "Extract of lingonberry" (MEDAGROPROM) (1.01\%), while "Lingonberry" (Danikafarm) (0.03\%) and "Lingonberry nano" (LSS SYSTEM) (0.04\%) were quite poor in hydroquinones.

All dietary supplements analyzed contain hydroquinone derivatives, flavonoids and hydroxycinnamic acids. However, the content of biological active substances is in minor amounts in "Lingonberry" (Danikafarm) and "Lingonberry nano"

Table. The total content of phenolic compounds, flavonoids, hydroxycinnamic acids and hydroquinone derivatives in the dietary

\begin{tabular}{|c|c|c|c|c|c|c|c|c|}
\hline \multirow[t]{2}{*}{ Preparation } & \multicolumn{2}{|c|}{$\begin{array}{l}\text { Total phenolic } \\
\text { compounds }\end{array}$} & \multicolumn{2}{|c|}{ Total flavonoids } & \multicolumn{2}{|c|}{$\begin{array}{l}\text { Total hydroxycinnamic } \\
\text { acids }\end{array}$} & \multicolumn{2}{|c|}{$\begin{array}{c}\text { Total hydroquinone } \\
\text { derivatives }\end{array}$} \\
\hline & $\%^{[a]}$ & $X^{[b]}$ & $\%$ & $\mathrm{x}$ & $\%$ & $\mathrm{x}$ & $\%$ & $x$ \\
\hline "Lingonberry" (Danikafarm) & 0.26 & $0.78 \mathrm{mg}$ & 0.15 & $0.59 \mathrm{mg}$ & 0.06 & $0.23 \mathrm{mg}$ & 0.04 & $0.16 \mathrm{mg}$ \\
\hline $\begin{array}{l}\text { "Lingonberry nano" } \\
\text { (LSS SYSTEM) }\end{array}$ & 0.30 & $1.10 \mathrm{mg}$ & 0.12 & $0.44 \mathrm{mg}$ & 0.13 & $0.48 \mathrm{mg}$ & 0.03 & $0.11 \mathrm{mg}$ \\
\hline $\begin{array}{l}\text { "Extract of lingonberry" } \\
\text { (MEDAGROPROM) }\end{array}$ & 8.70 & $87 \mathrm{mg} \mathrm{mL}^{-1}$ & 6.37 & $63.7 \mathrm{mg} \mathrm{mL}^{-1}$ & 0.94 & $9.4 \mathrm{mg} \mathrm{mL}^{-1}$ & 1.01 & $10.1 \mathrm{mg} \mathrm{mL}^{-1}$ \\
\hline
\end{tabular}
supplements in a dosage form

Notes: [a] the percentage of the biologically active compounds in 1 tablet ("Lingonberry" and "Lingonberry nano") and in the total volume of drops ("Extract of lingonberry"); [b] the content of the biologically active compounds in 1 tablet ("Lingonberry" and "Lingonberry nano") and in the total volume of drops ("Extract of lingonberry") 
(LSS SYSTEM) dietary supplements, and this fact casts doubt the quality of these dietary supplements.

According to the section of "Dietary supplements" of the State of Pharmacopoeia of Ukraine (2.0) [14] the minimum content of each vitamin and/or mineral substance (nutrients) in the recommended daily amount of dietary supplements should be at least $15 \%$ of the recommended daily intake. The regulation document of daily intake of nutrients "Norms of physiological needs of the population of Ukraine in basic nutrients and energy" [14] declares that daily intake of flavonoids is $250 \mathrm{mg}$. In this regard the recommended daily amount of flavonoids taken with a dietary supplement is $37.5 \mathrm{mg}$. According to the instructions for use of dietary supplements, 10 drops of "Extract of lingonberry" (MEDAGROPROM) are taken in $200 \mathrm{~mL}$ of water 3 times a day, 2 tablets of "Lingonberry" (Danikafarm) are taken 3 times a day, and 2 tablets of "Lingonberry nano" (LSS SYSTEM) are taken 3 times a day. Thus, a daily amount of flavonoids in "Extract of lingonberry" (MEDAGROPROM) is $110.49 \mathrm{mg}$, in "Lingonberry"
(Danikafarm) - $3.52 \mathrm{mg}$, and in "Lingonberry nano" (LSS SYSTEM) - $2.61 \mathrm{mg}$. The results obtained show that "Lingonberry" (Danikafarm) and "Lingonberry nano" (LSS SYSTEM) dietary supplements do not meet the requirements of the State of Pharmacopoeia of Ukraine 2.0 in relation to the recommended daily amount of nutrients of dietary supplements, therefore, these dietary supplements are of poor quality and cannot be recommended for application.

\section{- Conclusions}

"Extract of lingonberry" (MEDAGROPROM) dietary supplement meets the requirements of the State of Pharmacopoeia of Ukraine 2.0, whereas "Lingonberry" (Danikafarm) and "Lingonberry nano" (LSS SYSTEM) do not comply with the requirements.Based on the results of the study it can be concluded that the problem of compliance of dietary supplements is relevant today and requires the introduction of regulatory documentation for the detection and determination of biologically active substances in dietary supplements.

\section{- References}

1. Ștefănescu, B.-E.; Călinoiu, L. F.; Ranga, F.; Fetea, F.; Mocan, A.; Vodnar, D. C.; Crișan, G. Chemical Composition and Biological Activities of the Nord-West Romanian Wild Bilberry (Vaccinium myrtillus L.) and Lingonberry (Vaccinium vitis-idaea L.) Leaves. Antioxidants 2020, 9 (6), 495. https://doi.org/10.3390/antiox9060495.

2. Komisarenko, M. A.; Koshovyi, O. M.; Kovalova, A. M.; Sydora, N. V. Investigation of organic acids of Vaccinium vitis-idaea leaves. Collection of scientific works of staff members of NMAPE 2014, 23 (4), 291-295.

3. Komisarenko, N. A.; Geiderikh, A. S.; Kovaleva, A. M.; Koshevoy, O. N. The study of phenolic compounds of an alcoholic extract from the leaves of Vaccinium vitis-idaea. Ukrainian Journal of Clinical and Laboratory Medicine 2012, 7 (2), 24-226.

4. Bujor, O.; Ginies, C.; Popa, V. I.; Dufour, C. Phenolic compounds and antioxidant activity of lingonberry (Vaccinium vitis-idaea L.) leaf, stem and fruit at different harvest periods. Food Chemistry 2018, 252, 356-365. https://doi.org/10.1016/j.foodchem.2018.01.052.

5. Shamilov, A. A.; Bubenchikova, V. N.; Chenikov, M. V.; Pozdnyakov, D. I.; Garsiya, E. R. Vaccinium vitis-idaea L.: Chemical contents, pharmacological activities. Pharmaceutical Sciences 2020, 26 (4), 344-362. https://doi.org/10.34172/PS.2020.54.

6. Riihinen, K. R.; Ou, Z. M.; Gödecke, T.; Lankin, D. C.; Pauli, G. F.; Wu, C. D. The antibiofilm activity of lingonberry flavonoids against oral pathogens is a case connected to residual complexity. Fitoterapia 2014, 97, 78-86. https://doi.org/10.1016/j.fitote.2014.05.012.

7. Kowalska, K.; Olejnik, A.; Zielińska-Wasielica, J.; Olkowicz, M. Inhibitory effects of lingonberry (Vaccinium vitis-idaea L.) fruit extract on obesity-induced inflammation in 3T3-L1 adipocytes and RAW 264.7 macrophages. Journal of Functional Foods 2019, 54, 371-380. https://doi.org/10.1016/j.jff.2019.01.040.

8. Dróżdż, P.; Šèžienė, V.; Wójcik, J.; Pyrzyńska, K. Evaluation of Bioactive Compounds, Minerals and Antioxidant Activity of Lingonberry (Vaccinium vitis-idaea L.) Fruits. Molecules 2018, 23 (1), 53. https://doi.org/10.3390/molecules23010053.

9. Tsemenko, K. V.; Kireiev, I. V.; Komisarenko, M. A.; Koshovyi, O. M. Diuretic activity of phytosubstances from Vaccinium vitis-idaea leaves. Current issues in pharmacy and medicine: science and practice 2018, 11 (3), 312 - 317. https://doi.org/10.14739/24092932.2018.3.145276.

10. Tsemenko, K. V.; Kireev, I. V.; Komissarenko, M. A.; Koshovyi, O. M. The study of the analgesic activity of the modified extract from Vaccinium vitis-idaea leaves. The Pharma Innovation 2019, 8 (4), 929-931.

11. Nutritional Composition and Antioxidant Properties of Fruits and Vegetables; Jaiswal, A. K., Ed.; Academic Press: 2020.

12. Pro vnesennia zmin do deiakykh zakonodavchykh aktiv Ukrainy shchodo kharchovykh produktiv: Zakon Ukrainy vid 22.07.2014 No. 1602-VII: stanom na 4 kvit. 2018 r. [On Amendments to Certain Legislative Acts of Ukraine Concerning Food Products: Law of Ukraine, July 22, 2014 No. 1602-VII: revision on April 4, 2018, in Ukrainian]. https://zakon.rada.gov.ua/laws/show/1602-18\#Text (accessed Oct 1, 2021).

13. Denisenko, T. A.; Vishnikin, A. B.; Tsiganok, L. P. Reaction features of 18 -molibdodiphosphate and folin-ciocalteu reagent with phenolic compounds. Analytics and Control 2015, 19 (3), 242-251. https://doi.org/10.15826/analitika.2015.19.3.001.

14. Derzhavna farmakopeia Ukrainy: v 3 tomakh, 2 vydannia [The State Pharmacopoeia of Ukraine: in 3 volumes, $2^{\text {nd }}$ ed., in Ukrainian]; State Enterprise “Ukrainian Scientific Pharmacopoeial Center for Quality of Medicines": Kharkiv, 2014; Vol. 2. 
15. Nakaz MOZ Ukrainy vid 03.09.2017 No. 1073 “Pro zatverdzhennia Norm fiziolohichnykh potreb naselennia Ukrainy v osnovnykh kharchovykh rechovynakh i enerhii" [Order of the Ministry of Health of Ukraine No. 1073 dated 03.09.2017 "On approval of the Norms of physiological needs of the population of Ukraine in basic nutrients and energy", in Ukrainian]. https://zakon.rada.gov.ua/laws/show/ z1206-17 (accessed Oct 1, 2021).

\section{Authors information:}

Oleksandr Yu. Maslov (corresponding author), Teaching Assistant of the Department of Analytical Chemistry and Analytical Toxicology, National University of Pharmacy of the Ministry of Health of Ukraine; https://orcid.org/0000-0001-9256-0934;

e-mail for correspondence: alexmaslov392@gmail.com; tel. +380664257224.

Mykola A. Komisarenko, Ph.D. in Pharmacy, Teaching Assistant of the Department of Pharmacognosy, National University of Pharmacy of the Ministry of Health of Ukraine; https://orcid.org/0000-0002-1161-8151.

Serhii V. Kolisnyk, D.Sc. in Pharmacy, Professor, Head of the Department of Analytical Chemistry and Analytical Toxicology, National University of Pharmacy of the Ministry of Health of Ukraine; https://orcid.org/0000-0002-4920-6064.

Olga V. Antonenko, Ph.D. in Pharmacy, Associate Professor of Inorganic and Physical Chemistry Department, National University of Pharmacy of the Ministry of Health of Ukraine; https://orcid.org/0000-0002-0369-6520.

Olena V. Kolisnyk, Ph.D. in Pharmacy, Associate Professor of the Department of Pharmaceutical Chemistry, National University of Pharmacy of the Ministry of Health of Ukraine; https://orcid.org/0000-0003-0558-3164.

Tatyana A. Kostina, Ph.D. in Chemistry, Associate Professor of the Department of Analytical Chemistry and Analytical Toxicology, National University of Pharmacy of the Ministry of Health of Ukraine; https://orcid.org/0000-0001-5048-8575. 